\title{
Analysis Implementation Learning Adapted Physical Education in State High School
}

\author{
Pasca Tri Kaloka \\ Faculty of Sport Sciences \\ Yogyakarta State University \\ Yogyakarta, Indonesia \\ p.trikaloka@uny.ac.id
}

\author{
Sugeng Purwanto \\ Faculty of Sport Sciences \\ Yogyakarta State University \\ Yogyakarta, Indonesia \\ sugeng_purwanto@uny.ac.id
}

\author{
Yuyun Ari Wibowo \\ Faculty of Sport Sciences \\ Yogyakarta State University \\ Yogyakarta, Indonesia \\ yuyun_ariwibowo@uny.ac.id
}

\begin{abstract}
-implementation of adaptive curriculum in Yogyakarta High School is less optimal; this can be seen from the teacher's preparation especially in the curriculum of adaptive learning, teacher's seriousness, the readiness for facilities and infrastructure in the school, the enthusiasm of students, and the least evaluation of the learning program with the CIPP method. This research was conducted to develop and test the adapted physical education learning implementation in inclusive state high school including children with special needs. The data of Children with special needs was obtained by interview method. The quantitative survey method is aimed at giving an overview about the actual condition in a population. The essence of this study is to determine the implementation of physical education and the health of students with special needs at the inclusive physical education high school. They were used as case studies, and the process and product lasted for about a period of 2-months. Analysis of the data indicates that the teachers, students with special needs, and regular students benefited from the consultant model. The adapted physical education consultant model appears to be a viable approach in facilitating the integration of children with special needs. Based on the objectives and research results, it can be concluded that learning Adapted Physical Education at inclusive High School as a whole that includes context, inputs, processes and products including good category. However, there is one aspect, namely the process that included the $s$ average categories.
\end{abstract}

Keywords-physical education, adapted, special needs, high school.

\section{INTRODUCTION}

In developing countries, majority of children with disabilities do not go to school, while those of them, that are registered do not attend classes. Eliminating barriers that tends to prevent physically disabled persons proper access to education and learning is an important condition for actualizing Education for All. In order to ensure that all children have access to quality education, education policies and practices must be include all learners, encourage all learners to fully participate, and promote cultural differences as a source rather than an obstacle [1].

Education paves way for the prosperity of individuals and the society in general $[2,3]$. This research work is aimed at the development of a more inclusive school community. Recent researches has shown that the principal is the key to ensuring that the school functions properly. He /she collaborates with the teachers and non-academic staff to ensure that the school functions adequately.
We proposed a theory, which states that evaluation with the CIPP model will have a better impact than evaluation with other models.

\section{METHOD}

A high school agreed to participate in this investigation, following the approval by our university's institutional Review Board. This study involves the principal, physical education teachers, regular students and special needs students. The participants were properly notified and taught how to answer the questionnaires and interviews. The Participants ( both students and teachers) were encouraged to answer the interview questions which, was about 16 questions, after which they were asked to fill out the questionnaires. The Data obtained was recorded digitally by Sennheiser PX 100-II114 dB (1 kHz/1 Vrms).

The data was obtained from the interviews, teacher questionnaire, student questionnaire, teacher's scoring Instrument, appendix for the observation of infrastructure , and an attachment of the teaching and learning process in Physical education class that aided in the learning of Physical Education of Sport and Health at Inclusive High School. SPSS was used to analyze the data.

Lesson materials for learning was presented to Adapted High School. The syllabus was used as a guide in delivering the material. This means that the teacher, always used the syllabus as a guide when delivering materials for learning in Adapted High School [ the category of learners, the teachers' competence, and the facilities aid in the learning of physical education at adapted high school [7]. These inputs are incorporated in the learning processes. The existence of this aspect supports the implementation of the teaching and learning processes, so that the learning objectives can be achieved.

Physical education teachers play an important role in determining the success of implementing the learning activities in adapted classes. The Teachers' qualifications include the teacher's educational background, certification, work experience, training experience and workload [8]. These parameters were used to select qualified physical education teachers in adapted high school.

Success in every learning process is determined by several factors, one of which is the provision of standard 
facilities that support the learning process. Without adequate facilities, the learning process will not run smoothly. In addition, there would be few graduates because of limited or substandard facilities. Assessing the processes of learning activities including preparation, implementation, and assessment of learning outcomes. Preparation of teachers in learning activities include preparation using learning materials and preparation via the media. We learnt about physical sports education through questionnaires from students and teachers, and by observing the activities of physical education, such as opening activities, main activities, and closing activities. The Competence of the students after learning sports education $[9,10]$. Includes the value of physical education report cards and mastering the characteristics of the sports.

\section{RESULT}

The data obtained is summarized in table 1. According to the questionnaire, how many Lesson materials were presented in Adapted High School? Four persons answered correctly how many syllabus were contained in the lesson materials. This question got a score of 3 out of a maximum score of 4 or with a percentage of $80 \%$ in this category. Teachers based their answers on the questionnaires, often using the syllabus as their reference in delivering the subject matter judging from the contents of the syllabus, the teachers' answers were based on the questionnaire, in accordance with core competencies and basic competencies. This answer got a score of four out of a maximum score of 4 or with a $100 \%$ percentage. The average teacher had a score of 3.85 or with a percentage of $90 \%$, this proves that the teacher's subject matter is good.

The teacher learning questionnaire in Adapted High School consists of 10 item statement the data obtained had 32 as the lowest score and 40 as the highest score, while the mean price (mean) is 36 , and standard deviation 1.33 . From the results obtained on teacher context evaluation above, it can be concluded that the average score obtained is $86.7 \%$, therefore the result of the questionnaire on the teacher's context was included in the good category.

The questionnaire on the teachers' input evaluation in learning Physical Education in Adapted High School consists of 10 item statements. The data obtained had 30 as the lowest score and 37 as the highest score, with a mean price (mean) of 33.5, and standard deviation of 1.16. The average score obtained is $74 \%$, therefore the result of the questionnaire on the teachers' input was included in average category.

The teachers' Questionnaire on the evaluation process consist of 11 points statement the data obtained had its lowest score as 33 and the highest score as 39, with a mean price (mean) of 36 , and standard deviation of 1 . The average score obtained is $82,27 \%$, therefore the result can be included in the good category

This teachers' questionnaire consists of 4 points statement on product in learning Adapted physical education at Inclusion State High School. The data obtained had 11 as its lowest score as and 16 as its highest score 16, the mean price (mean) is 13.5 , and standard deviation of 0.83 .
$86,75 \%$, was obtained as the result and can be included under the good category.

Regular Student factor questionnaire consists of 5 items of statement in learning Physical Education at Adapted High School. The data obtained had a very low score of 11 and the highest score was 20 , while the average price (mean) was 15.5 , and standard deviation of 1.5. The average score obtained was $78 \%$, therefore, the results of the questionnaire on student context could be placed under good category. The questionnaire for learners in learning physical education Adapted High School consists of 10 item statement inputs. Student data obtained the lowest score to be 23 and the highest score 40, while an average price (mean) of 31.5 , and standard deviation of 2.83. The results of questionnaires input evaluation of the above students can be concluded that the average score obtained as much as $78.82 \%$, the results of questionnaires input can be included in the good category.

This questionnaire consists of 10 points statement process in the student questionnaire in learning at Adapted High School. According to the Students' data obtained the lowest score was 17 and the highest score 40, with an average price (mean) of 28.5 , and standard deviation of 3.83.The $73.25 \%$, was obtained as the result and should be included in the good category.

The learner's questionnaire in learning Adapted Physical Education at Inclusion State High School consists of 5 item statements on products. Teacher data obtained the lowest score of 10 and the highest score 20, with a mean price (mean) of 15, and standard deviation of 1.6. $77.8 \%$ was gotten as the result and was, included in good category.

Student with special needs questionnaire consists of 5 items of statement in the context on the students' questionnaire in learning Adapted Physical Education at Inclusion State High School. The Student data had the lowest score of 11 and the highest score of 20, while the average price (mean) was 18.5 , and standard deviation of 1.8 . It was concluded that the average score obtained was $85 \%$, was in the good category.

Questionnaire consists of 10 items statement of evaluation inputs in the learner's questionnaire in learning adapted physical education at Inclusion State High School. The Students' data had the lowest score of 15 and a very high score of 35 , an average price (mean) of 25.6, and standard deviation of 2 . The results of questionnaires input evaluation obtained is $65 \%$, hence, was included in the average category.

This students' questionnaire consists of 10 points statement process of learning at Inclusion State High School. The Student data got 18 as the lowest score and 38 as the highest score, the average price (mean) was 28.5, and standard deviation was 3.5. According to The results, the average score obtained was $70.45 \%$, so that results of student questionnaires process was included in the good category.

This questionnaire consists of 5 items statement in the products of learning Physical Education at Adapted High 
School. The Teacher data had the lowest score of 7 and 16 as the highest score, while the mean price (mean) was 12 , and standard deviation of 1.4. From the Results, the average score obtained is $68.5 \%$, is included in the average category.

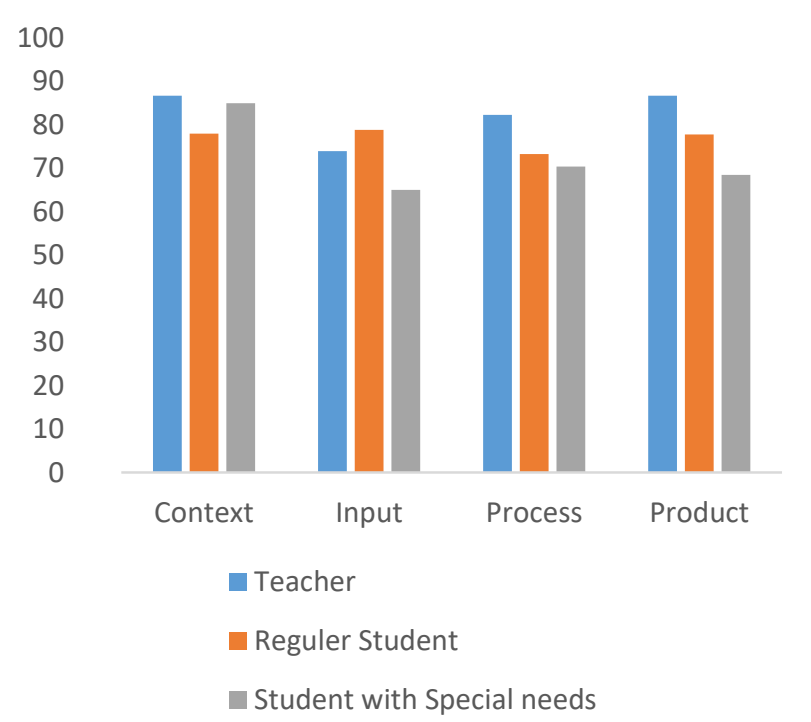

Fig. 1. Total Conclusion Evaluation of context, input, process and product

\section{DISCUSSION}

This is the first study to analyze the learning of adapted physical education at inclusion state high school using the input, process, and product methods. Result obtained from learning Adapted Physical Education at Inclusion State High School was evaluated by context, input, process and product methods with the respondents (students and teachers), and data collection techniques stated in the questionnaire below.

It was concluded that the Teachers were good at context, average at input, and good at process and good at product. It was also concluded that the students were good at context, input, process, and product. For the students with special needs it was concluded that they were good at context, average at input, and average at process and good at product.

After further analysis, we deduced that the most dominant context, input, process, and product was in the aspect of facilities, infrastructure and in the evaluation of inputs with a percentage of 100. The least dominant aspect of learning Physical education in the State Senior High School in the city was on the evaluation process and the learning process. Thus, it can be seen that the aspects of facilities and infrastructure are the supportive factors for learning Physical education in Yogyakarta State Senior High School.

\section{CONCLUSION}

Based on the objectives and research results, it can be concluded that learning Adapted Physical Education in High School consists of context, inputs, processes and products found under good category. The Categories were interpreted as inadequate in some situations whereas context, inputs and products were interpreted to be good. More detailed conclusions for each aspect are as follows:

\section{Context Evaluation Results}

The results of the context evaluation indicates that the relevance of standard education for the primary and secondary educational units, and the competency standards of senior high school graduates is dependent on the syllabus , the educational and cultural ministerial regulation number 64 of 2013 .

\section{Input Evaluation Results}

The characteristics of learners of Physical Education were placed under the good category. The characteristics or background of the Physical Education teachers, are included in the good category. Facilities and infrastructure including those that need to be worked on.

\section{Process Evaluation}

Physical Education learning in High School includes process that such as learning preparation, core activities, and assessment of learning outcomes.

\section{4) Product Evaluation}

Learning Physical Education in High School this consists of the learners' value, spirit of sportsmanship and the ability in managing the daily exercise schedule.

Evaluation results are included in the good category but there is one variable that involves processes such as preparation, learning activities ( preliminary activities), core activities( teaching and learning activities); closing and appraisal activities. This shows that the implementation of learning Adapted Physical Education at High School has not yet started.

PE learning is now very common in schools. the relevant authorities such as the principals and supervisors ensure the smooth running and learning of physical education in schools One of the goals of learning physical education is to produce competent graduates.

Another very important facility that demands attention is the presence of a field. Elementary schools or junior high schools should have a field for the various sporting activities. for example State High School 1 of Sewon Bantul has a standard field., It is expected that in the near future there will be time management or an agreement to use the field so that the teaching and learning processes can be carried out effectively.

The implementation of this research was carried out to suit the research objectives, but there were still some limitations and weaknesses that cannot be avoided, such as:

1. The researchers had limited resources.

2. Some issues were encountered from the respondents that filled out the questionnaires, such as reluctance, fatigue, dishonesty and not understanding the purpose of the item. 
3. It was observed that some respondents felt some discomfort at the time the research was conducted.

Based on the results of this research and conclusions, some suggestions were made for future references. Others:

1. Principals and supervisors need to pay attention to the implementation or learning process.

2. Schools need to complete include teaching materials like textbooks, modules, learning CD's in order to broaden the subject matter becomes broader.

3. Teachers are expected to attend teacher trainings and join PE teachers' association in order to have more insight of teaching and learning activities in schools.

4. The teacher is expected update the syllabus and lesson plan from time to time.

5. Teachers are expected to be able to improve their knowledge of $\mathrm{PE}$, the use of instructional media, especially the use of LCD's and the use internet technology.

6. Teachers are expected to motivate and facilitate the students in applying the knowledge gained from Physical Education.

7. The school is expected to be able to manage or have an agreement on Physical Education learning time.

\section{REFERENCES}

[1] Embracing Diversity, "Toolkit for creating inclusive, learning-friendly environments specialized booklet 3 - Teaching Children with Disabilities in Inclusive Settings". UNESCO Bangkok, 2009.

[2] S. Carrington, R. Robinson, "Inclusive school community: why is it so complex?", International Journal of Inclusive Education, 2006, vol. 10, pp. 4-5.

[3] S. Carrington, K. Holm, "Students direct inclusive school development in an Australian secondary school: an example of student empowerment", Australasian Journal of Special Education, 2005, vol. 29 , no. 2, pp. 155-171.

[4] N. L. Waldron, J. McLeskey, L. Redd, "Setting the direction: the role of the principal in developing an effective, inclusive school", Journal of Special Education Leadership, 2011, pp. 51-60.

[5] D. L. Stufflebeam, "Institutionalizing evaluation in schools". In The international handbook of educational evaluation (Chapter 34), D. L. Stufflebeam, and T. Kellaghan, (Eds.)". Boston: Kluwer Academic Publishers, 2003.

[6] J. Kugelmass, "Collaboration and compromise in creating and sustaining and inclusive school", International Journal of Inclusive Education, 2001, vol. 5, no. 1, pp. 47-65

[7] K. L. Combs, S. K. Gibson, J. M. Hays, J. Saly, J. T. Wendt, "Enhancing curriculum and delivery: linking assessment to learning objectives", Assessment and Evaluation in Higher Education, 2008, vol. 33 , no. 1 , pp. 87-102.

[8] J. Kugelmass, "Collaboration and compromise in creating and sustaining and inclusive school". International Journal of Inclusive Education, 2001, vol. 5, no. 1, pp. 47-65.

[9] C. Furrer, E. Skinner, "Sense of relatedness as a factor in children's academic engagement and performance", Journal of Educational Psychology, 2003, vol. 95, no. 1, pp. 148-162.

[10] A. Hargreaves, D. Fink, "The seven principles of sustainable leadership", Educational Leadership, 2004, vol. 61, no. 7, pp. 8-13.

[11] G. Zhang, N. Zeller, R. Griffith, D. Metcalf, "Using context, input, process, and product evaluation model (CIPP) as a comprehensive framework to guide the planning, implementation, and assessment of learning program", Journal of Higher Education Outreach and Engagement, 2011, vol. 15, p. 57.

[12] R. Slee, "Driven to the margins: disabled students, inclusive schooling and the politics of possibility", Cambridge Journal of Education, 2001, vol. 31 , pp. 385-397.

[13] D. Butin, "Of what use is it? Multiple conceptualizations of service learning within education". Teachers College Record, 2003, vol. 105, no. 9 , pp. 1674-1692.

[14] S. Ash, P. Clayton, "The articulated learning: An approach to guided reflection and assessment. Innovative Higher Education", 2004, vol. 29 , no. 2, pp. $137-154$. 